\title{
Organic geochemical study of the "W" oil-gas field in the Yugoslav part of the Pannonian basin
}

\author{
M. M. ŠabaN ${ }^{1,2 *}$, B. S. JovanČIĆEvić 2 , T. GlumičIĆ ${ }^{2}$ and S. SARAČevic ${ }^{3}$ \\ ${ }^{1}$ Faculty of Chemistry, University of Belgrade, P.O. Box 550, 11001, Belgrade, Yugoslavia \\ ${ }^{2}$ Institute of Chemistry, Technology and Metallurgy, Belgrade, Yugoslavia \\ ${ }^{3}$ Nafta-gas, Novi Sad, Yugoslavia
}

(Received 17 September 1989; accepted 22 January 1990)

\begin{abstract}
The naphthenic crude oil from the "W" oil-gas field differs from almost all other, paraffinic base oils discovered until now in the Yugoslav part of the Pannonian basin. In order to explain this difference, some geological and organic geochemical investigations were carried out.

On the basis of the bulk and biomarker parameters, determined in oil samples taken from 13 producing wells located at different parts of the field, it is concluded that the crude oil throughout the field has an almost uniform composition. However, some differences in alkane content, due to biodegradation and/or water washing were found. In the northeast part of the field where a tilted oil-water layer shows an active hydrodynamism, and where the temperatures are the lowest and pressure gradients the highest, the isoprenoids pristane and phytane were detected in trace amounts-indicating the most intensive biodegradation. In the central part, where a hydrocarbon accumulation exists in a Miocene reservoir, somewhat lower biodegradation was observed.

The crude oil from this field has probably a mixed terrestrial-marine origin and is derived from argillaceous source rocks sedimented in marine delta or brackish lakes.

Specific maturation parameters confirmed that the " $W$ " crude oil has reached a quite uniform and significant thermal maturation. Considering maturation parameters such as ratios $\mathrm{C}_{30}$ moretane/hopane and $\mathrm{C}_{29} \alpha \alpha(20 S) / \alpha \alpha(20 S)+(20 R)$ steranes, as well as the presence of oleanane, it could be proposed that the "W" oil originates from a Pre-Tertiary source rock, at least an Upper Cretaceous one, unlike most Pannonian basin oils which are Tertiary in age.
\end{abstract}

Key words -oil-gas field, Pannonian basin, Yugoslavia, oil composition, origin and maturity, biomarkers, stereoisomers

\section{INTRODUCTION}

The investigated " $W$ " field contains one of the most productive reservoirs in the southeastern part of the Pannonian basin in the territory of Vojvodina (Yugoslavia). The "W" oil is among the few oils in this region which are naphthenic. Other oils in Vojvodina are mainly paraffinic (Šban et al., 1988 and unpublished results). The scope of the investigations was to establish if the difference was due to the origin of the crude or to degradation by bacterial attack and/or water washing. Both processes are known (e.g. Price, 1980) to change light, paraffinic, low-sulfur, "mature" crude into heavy, naphthenic or asphaltic, immature looking, high-sulfur crude. Previous studies (Karović et al., 1969; Sarković, 1972) should be updated with additional geologic data on the "W" structure. Also, oil samples from 13 wells located in various parts of the field were tested for those molecular parameters which define the origin, maturity and possible changes in the reservoir.

\section{GEOLOGY OF THE INVESTIGATED OIL-GAS FIELD}

The "W" oil-gas field is located in the southeastern part of the Pannonian basin, in northeastern

"Author to whom all correspondence should be addressed.
Yugoslavia (Fig. 1). The structural feature associated with the oil accumulation is a north-south trend which separates the depressions of Banat and south Bačka.

The oldest rocks of the " $W$ " feature are crystalline schists and gneiss, drilled in the central, north and northeast parts of the structure. A Paleozoic age was assumed on the basis of lithologic analogy. Triassic carbonates were recorded in the central, south and east parts of the structure. These carbonates are the shallowest in the east, where they are immediately overlain by Lower Pliocene clastics, and considerably deeper on the south flank of the structure. PreBadenian and Badenian sediments, including clays, shales, sandstones, tuffites, organic and detritic limestones, were deposited in lacustrine and marine environments, respectively. The crystalline schists and the Triassic carbonates are unconformably overlain by lacustrine sediments. The marine deposits extend mainly in the south, west and north parts of the structure. Three depositional units can be distinguished in the Pliocene and Quaternary sediments: sandstones and a marly unit, deposited in brackish water during Pontian, and the thick, clayey-sandy facies Paludine and Quaternary in age.

Structure "W" is a typical anticline formed by compaction of Neogene sediments on an uplifted, 


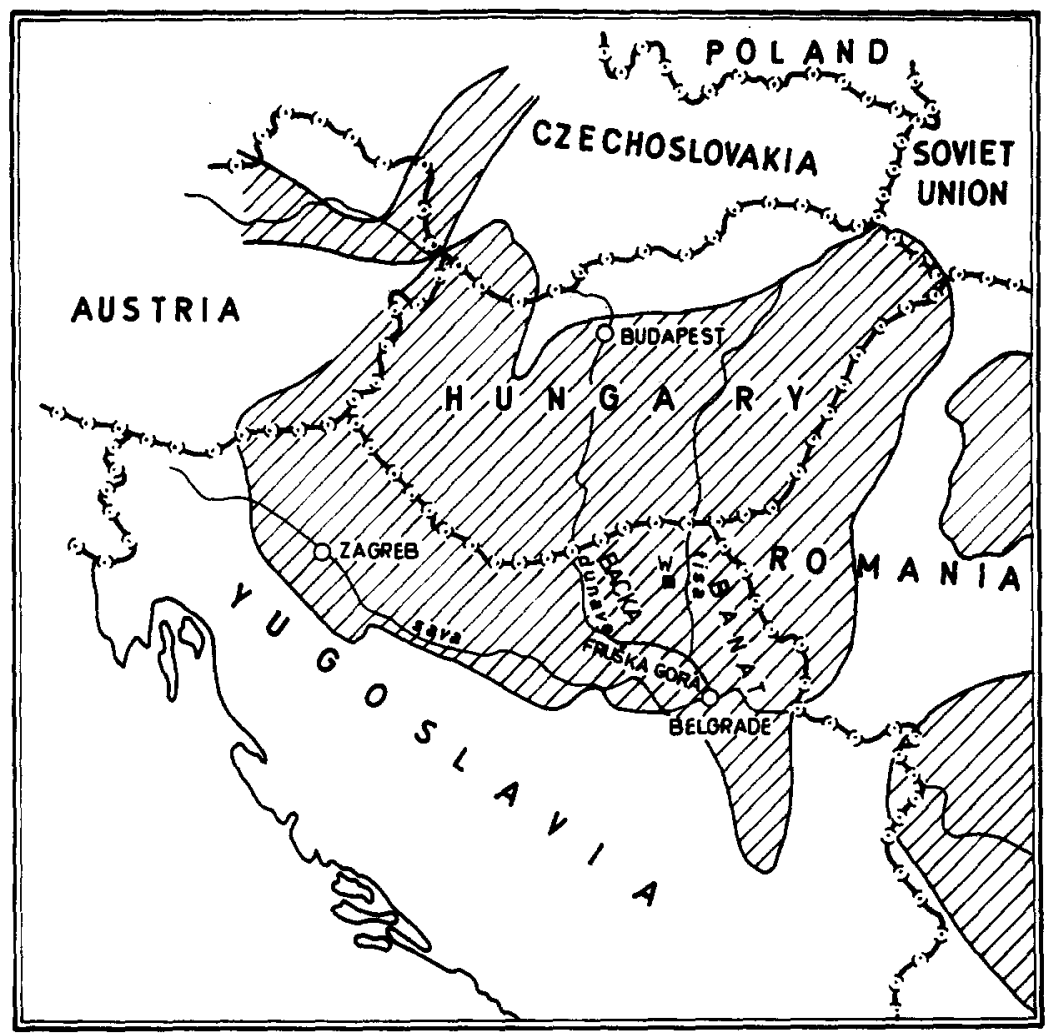

Fig. 1. Schematic view of Pannonian Basin. The field location is indicated as a black rectangle.

Paleozoic (?) and Mesozoic relief (Fig. 2). The tectonic activities that created the structure took place in various times, mainly in Pre-Neogene and Neogene. During the long Pre-Neogene depositional period, the area was uplifted and subsequently eroded. In the central part of the structure, a PostTriassic fault (not shown in Fig. 2) extends from northeast to southwest and limits the crystalline basement and the Mesozoic carbonates. From the point of view of petroleum geology, most important is the fault of the northeast-southwest trending, parallel with the Post-Triassic fault, which limits the field (Fig. 2) by downthrowing the northwest flank of the structure. This faulting occurred in the Pontian, before the accumulation of hydrocarbons and it defined the final shape of the trap. The northwestsoutheast oriented Paludine fault downthrew the southwest block of the structure from 10 to $30 \mathrm{~m}$ (Fig. 2) and it set no barrier for hydrocarbon migration and accumulation.

Pontian sandstones, which extend over rocks of various ages all over the structure and which are capped by the marly unit, form the most important reservoir rocks of the field. Their porosity values range from 22 to $35 \%$. The average permeability is high $(1340 \mathrm{mD})$. The water saturation is rather low, with an average of $14 \%$.

The "W" field also contains minor reservoirs, such as the Miocene lacustrine deposits, the Mesozoic carbonates and the weathered Paleozoic crystalline schists. However, the reserves contained in these rocks are negligible as compared to the reserves contained in the major, Pontian accumulation. At present, only two wells produce oil from the Miocene lacustrine deposits: W-120 and W-126. It remains to be established if the Miocene and Pliocene oil accumulations are interconnected.

The reservoir is a complex combination of bedded and massive sandstones and the trap is both stratigraphic and structural [Figs 3(a) and 3(b); Aksin (1967)].

The formation temperature at the average depth of the reservoir, calculated as $658 \mathrm{~m}$ s.s., ranges from 59 to $73^{\circ} \mathrm{C}$. The temperature is highest in the south and lowest in the north. The initial static pressure was $76.4 \mathrm{~atm}$ at $658 \mathrm{~m}$ s.s. and $74.9 \mathrm{~atm}$ at the absolute gas-oil contact level of $641 \mathrm{~m}$ s.s. The highest pressure gradients are in the northeast part of the reservoir.

The gas-oil contact is horizontal and at $641 \mathrm{~m}$ s.s. The oil-water contact is tilted in the Pontian sandstones, at $685 \mathrm{~m} \mathrm{s.s.} \mathrm{in} \mathrm{the} \mathrm{east} \mathrm{and} \mathrm{north} \mathrm{and} \mathrm{at}$ $669 \mathrm{~m}$ s.s. in the south and southeast. The oil-water contact at the base of the Triassic carbonates apparently forms a single unit with the Pliocene reservoir rocks, as established in W-68 at $675 \mathrm{~m}$ s.s. In the Pliocene reservoir, with exceptionally good petrophysical properties, no lithologic heterogeneities were noted, at least none that would act as barriers and produce an inclined oil-water contact. The inclined oil-water contact was interpreted as being due to the effect of meteoric water coming from the Fruška 

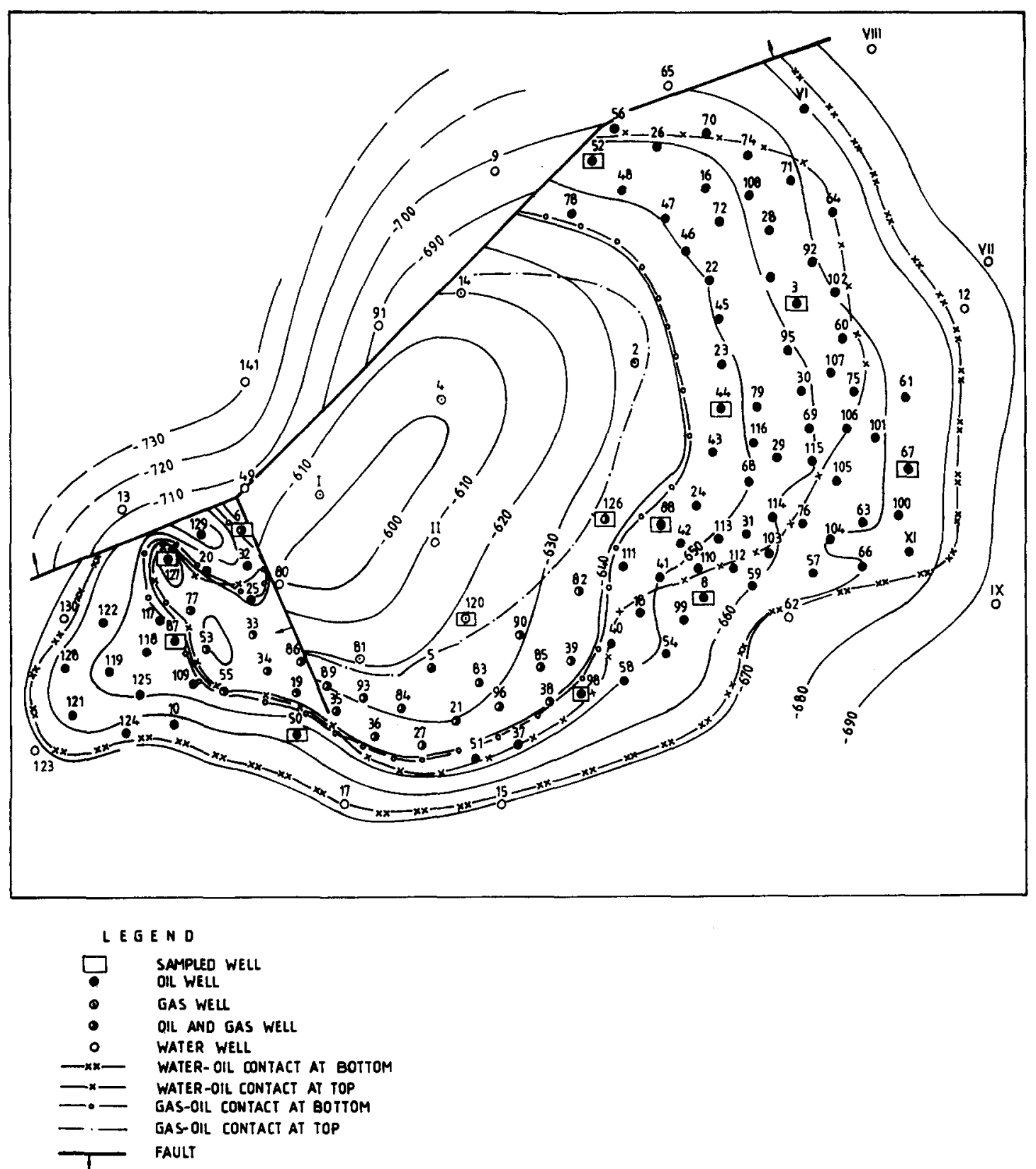

Fig. 2. Structural map of the "W" field on top of the Pliocene clastics.

Gora, a mountain about $60 \mathrm{~km}$ far from the "W" field, through the Mesozoic carbonates. The facts that the lowest temperatures and the highest pressure gradients were recorded in the northeast part of the reservoir and that the oil-water contact tilts in the eastern part of the reservoir, where the Pliocene rocks are immediately overlying the Triassic carbonates, would support this hypothesis.

The interpretation of the available geologic and well test data leads to the conclusion that the Pontian sandstones, the Mesozoic carbonate rocks and the crystalline schists represent a single accumulation. However, it is not clear if the Miocene hydrocarbon accumulation belong to the same hydrodynamic system or not. The low energy of these reservoir rocks implies either small amounts of oil in place or little communication with the Pliocene aquifer.

\section{SAMPLING AND ANALYTICAL TECHNIQUES}

The oil samples were taken from 13 production wells indicated on the structural map (Fig. 2). The geological data related to the reservoir rocks are presented in Table 1.

The API gravity was determined according to IP Standard No. 260/68 (1977). The sulfur content was determined by Schöniger microanalysis. The vanadium and nickel contents were determined by the atomic absorption method in oil ash obtained after igniting a $30 \mathrm{~g}$ oil sample in the presence of $3 \mathrm{~g}$ sulfur. 


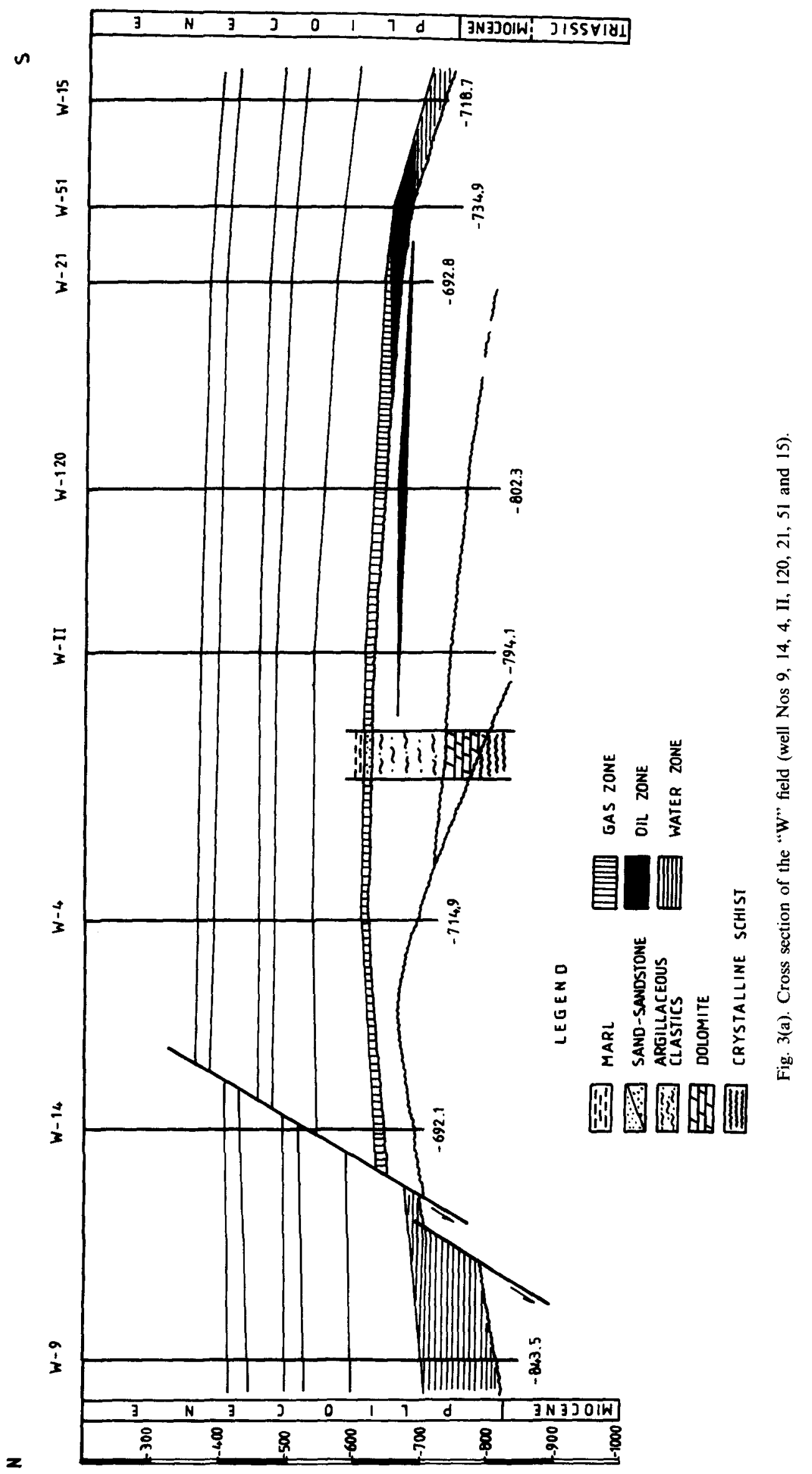




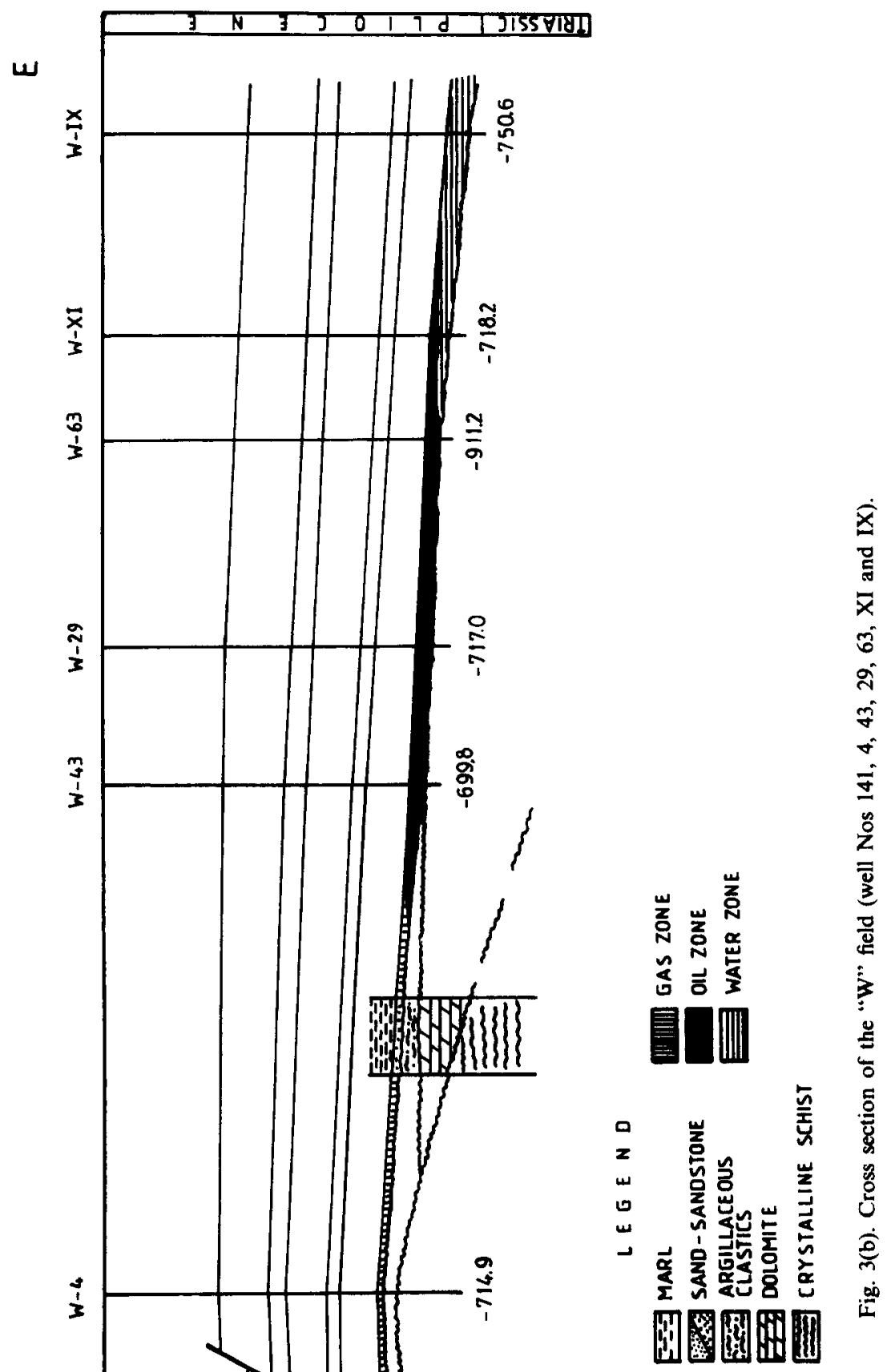


Table 1. Geological data on the reservoirs where the analyzed oils were sampled

\begin{tabular}{|c|c|c|c|c|}
\hline $\begin{array}{c}\text { Well } \\
\text { No }\end{array}$ & $\begin{array}{l}\text { Perforated Interval } \\
\text { (m) }\end{array}$ & Age & Lithology & Temperature $\left({ }^{\circ} \mathrm{C}\right)$ \\
\hline$W-120$ & $756-758$ & Miocene & Sandstone & $\mathrm{ND}$ \\
\hline W- 126 & $769-773$ & Miocene & Sandstone & ND \\
\hline$W-9 B$ & $752-758$ & Pliocene & Sand, sandstone & ND \\
\hline W-88 & 1 & Pliocene & Sand & 65.3 \\
\hline$W-8$ & $759-762$ & Pliocene & Sandstone & 66.8 \\
\hline$w-50$ & $760-762$ & Pliocene & Sand, sandstone & 62.0 \\
\hline W-87 & 1 & Pliocene & Sand & 60.9 \\
\hline$W-6$ & $753-757$ & Pliocene & Sandstone & 68.0 \\
\hline$w-52$ & $758-764$ & Pliocene & Sand, sandstone & ND \\
\hline$W-127$ & $747-751$ & Pliocene & Sand, sandstone & ND \\
\hline$W-44$ & $748-753$ & Pliocene & Sand, sandstone & 70.0 \\
\hline$w-3$ & $769-773$ & Pliocene & Sandstone & 63.0 \\
\hline$W-67$ & $778-781$ & Pliocene & Sand, sandstone & 64.0 \\
\hline
\end{tabular}

The asphaltenes were precipitated in a treatment with $n$-heptane for $16 \mathrm{~h}$ at room temperature and for $15 \mathrm{~min}$ at the solvent boiling temperature. The solvent and the low boiling components were removed from the filtrate at $50^{\circ} \mathrm{C}$ in a rotating vacuum evaporator. The obtained $\mathrm{C}_{15+}$ fraction was separated into saturated, aromatic and polar fractions using column chromatography (silica gel; petrol-ether, mixtures of petrol-ether and benzene and mixtures of methanol and chloroform as developers). Gas chromatography (GC) of the saturated hydrocarbons and urea adducts and gas chromatography-mass spectrometry (GC-MS) of urea nonadducts were performed as previously described (Šaban et al., 1988).

\section{RESULTS AND DISCUSSION}

The geological data (Figs 1-3 and Table 1) show that the hydrocarbon accumulation is at shallow depth, $<1000 \mathrm{~m}$, with the reservoir temperature ranging from 59 to $73^{\circ} \mathrm{C}$ and a tilted oil-water contact level. Under these conditions in situ changes of oil composition by biodegradation and/or water washing, processes which could account for the naphthenic character of the crude, may occur. On the contrary, changes due to thermal maturation in the reservoir are unlikely. The bulk and specific, organogeochemical parameters were evaluated with the goal of establishing if, and to what extent, these changes occurred in the whole field or parts thereof.

The bulk parameters given in Table 2 show that there are no significant differences between the analyzed samples.

$\mathrm{API}^{\circ}$ values range between 23 and $25^{\circ}$, sulfur content between 0.4 and $0.6 \%$, asphaltenes between 0.1 and $1 \%$, maltenes between 85 and $89 \%$ (except for samples $W-120$ and $W-126$, where the values are

Table 2. Bulk parameters of the analyzed oil samples

\begin{tabular}{|c|c|c|c|c|c|c|c|c|c|}
\hline $\begin{array}{l}\text { Well } \\
\text { No }\end{array}$ & $\mathrm{API}^{\circ}$ & $\underset{(\%)}{\text { sulfur }}$ & $V / N_{1}$ & $\begin{array}{c}\text { Asphal tenes } \\
(\%)\end{array}$ & $\begin{array}{c}\text { Maitenes } \\
(x)\end{array}$ & $\begin{array}{l}\text { Volatile } \\
\text { components } \\
(4)\end{array}$ & $\begin{array}{l}\text { Satur. HC } \\
\text { relat. to toit. } \\
\text { (x) }\end{array}$ & $\begin{array}{l}\text { Aratics } \\
\text { relat. to malt. } \\
(\%)\end{array}$ & $\begin{array}{l}\text { Polar comp. } \\
\text { relat. to malt. } \\
(\%)\end{array}$ \\
\hline$W-120$ & 24.1 & 0.55 & 0.13 & 0.19 & 54.11 & 45.70 & 60.96 & 16.78 & 22.26 \\
\hline$W-126$ & 25.3 & 0.57 & 0.07 & 0.22 & 79.29 & 20.49 & 62.06 & 16.07 & 21.87 \\
\hline W-98 & 25.5 & 0.42 & 0.50 & 0.34 & 89.01 & 10.62 & 65.97 & 17.12 & 16.91 \\
\hline W-88 & 23.3 & 0.41 & 0.11 & 0.96 & 87.64 & 11.40 & 69.25 & 15.50 & 15.25 \\
\hline$W-8$ & 24.2 & 0.41 & 0.19 & 0.11 & 85.96 & 13.93 & 55.96 & 17.04 & 27.00 \\
\hline$w-50$ & 23.9 & 0.44 & 0.16 & 0.26 & 86.23 & 13.57 & 57.82 & 16.28 & 25.90 \\
\hline$W-87$ & 23.3 & 0.39 & 0.20 & 0.35 & 86.32 & 13.33 & 66.31 & 15.65 & 18.04 \\
\hline$w-6$ & 25.0 & 0.54 & 0.33 & 0.19 & 89.11 & 10.70 & 62.70 & 17.99 & 19.31 \\
\hline$w-52$ & 23.9 & 0.57 & 0.32 & 0.56 & 85.06 & 14.38 & 57.72 & 20.36 & 21.92 \\
\hline W-127 & 22.8 & 0.59 & 0.20 & 0.58 & 87.41 & 12.01 & 56.97 & 18.73 & 24.30 \\
\hline$w-44$ & 23.8 & 0.35 & 0.26 & 0.08 & 85.12 & 14.80 & 64.43 & 94.71 & 20.86 \\
\hline W-3 & 23.4 & 0.39 & 0.24 & 0.14 & 85.05 & 14.81 & 63.88 & 16.60 & 19.52 \\
\hline$W-67$ & 23.0 & 0.54 & ND & 0.57 & 84.06 & 15.37 & 58.11 & 16.50 & 25.39 \\
\hline
\end{tabular}


much lower) and those of the volatile components between 11 and $15 \%$ (except in the case of sample W-120 and, to some degree, W-126). There is a major difference in the V/Ni ratio; samples W-120, W-126 and W-88 exhibit values which may correspond to fresh water environments, while the values of other samples fall within the limits characteristic of marine environments (Mello et al., 1988). Further, differences exist in the maltene group analysis: $56-69 \%$ of saturated hydrocarbons, $15-20 \%$ of aromatics and $15-26 \%$ of polar compounds.

The similarities and dissimilarities among the oil samples are better established when using specific parameters like the distribution of $n$-alkanes, pristane and phytane, tri- and tetracyclic terpanes, pentacyclic triterpanes, such as hopane, gammacerane and oleanane, and $\mathrm{C}_{27}-\mathrm{C}_{29}$ steranes.

In the gas chromatograms of saturated hydrocarbons, the peaks corresponding to pristane and phytane dominate [a typical example is shown in Fig. 4(a)]. The peaks generated by $n$-alkanes are small and of similar intensities to the large number of another peaks [Figs 4(a) and 5(a)], a good indication of a moderate biodegradation of the pooled oil (e.g. Volkman et al., 1983). The values of the temperatures measured in the reservoir (Table 1), lower than or close to the threshold of microorganism activity (77 ${ }^{\circ} \mathrm{C}$; Philippi, 1977; Alexander et al., 1983), seem to support this statement. Only in the cases of W-120 and $\mathrm{W}-126$ was a homologous series of $n$-alkanes, $\mathrm{C}_{16}-\mathrm{C}_{34}$, reliably proved to be in the urea adduct [Fig. 4(b)]. In the urea adducts of other samples, particularly of W-3, W-44 and W-67, only traces of $n$-alkanes were detected [Fig. 5(b)]. Therefore, the values of CPI are not representative. Biodegradation did affect the chemical composition of the analyzed samples and hence the origin of the oil cannot be established using the abundance and distribution of $n$-alkanes.

Real proof that biodegradation is currently active in the "W" field is the isolation of lipolitic bacteria in the aquifer of wells W-52 and W-3. The growth of these bacteria depends on paraffinic feed (Gajin, 1989).

The hydrocarbon composition of the urea adduct of crude oils W-120 and W-126 (Miocene hydrocarbon accumulation, Figs 3(a) and 4(b)] indicated that this part of the structure (Fig. 2) is not in direct contact with formation water.

Phytane dominates over pristane in all the samples analyzed $[\operatorname{Pr} / \operatorname{Py}<1$, Table 3 and Fig. 4(a)]. $\operatorname{Pr} / \mathbf{P y}$ values range from 0.35 to 0.59 ; the greatest ratio was encountered in oil samples from wells W-120, W-126 and $\mathrm{W}-127(0.55,0.57$ and 0.59 , respectively). The higher phytane content in relation to that of pristane is probably due to reduction processes prevailing at the time of source rock deposition (Welte and Waples, 1973; ten Haven et al., 1985, 1987) and/or to the contributions of marine source rocks in the genesis of the crude oils from field "W" (ten Haven et al., 1985, 1987; Powell and Mckirdy, 1973). Since during oil maturation phytane is generated more rapidly than pristane (Waples, 1985), the established value of $\operatorname{Pr} / \operatorname{Py}(<1)$ could be in response to higher maturity. Unlike the other samples, W-3, W-44 and W-67 contain only traces of pristane and phytane (Fig. 5). This would prove that the biodegradation of the oil in the northeast part of the field was more significant.

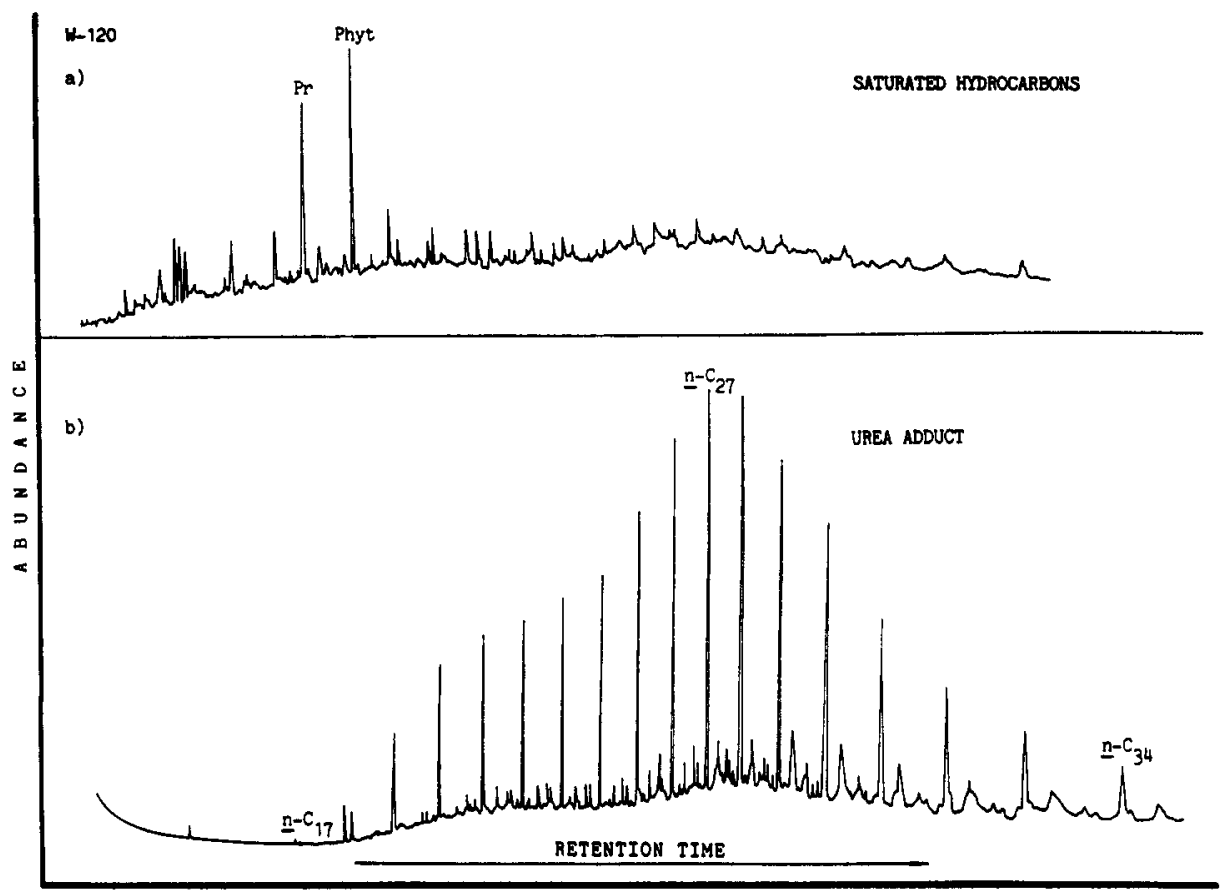

Fig. 4. Capillary gas chromatograms of the saturated hydrocarbons (a) and urea adduct (b) of the crude oil sample W-120, showing minor biodegradation. 


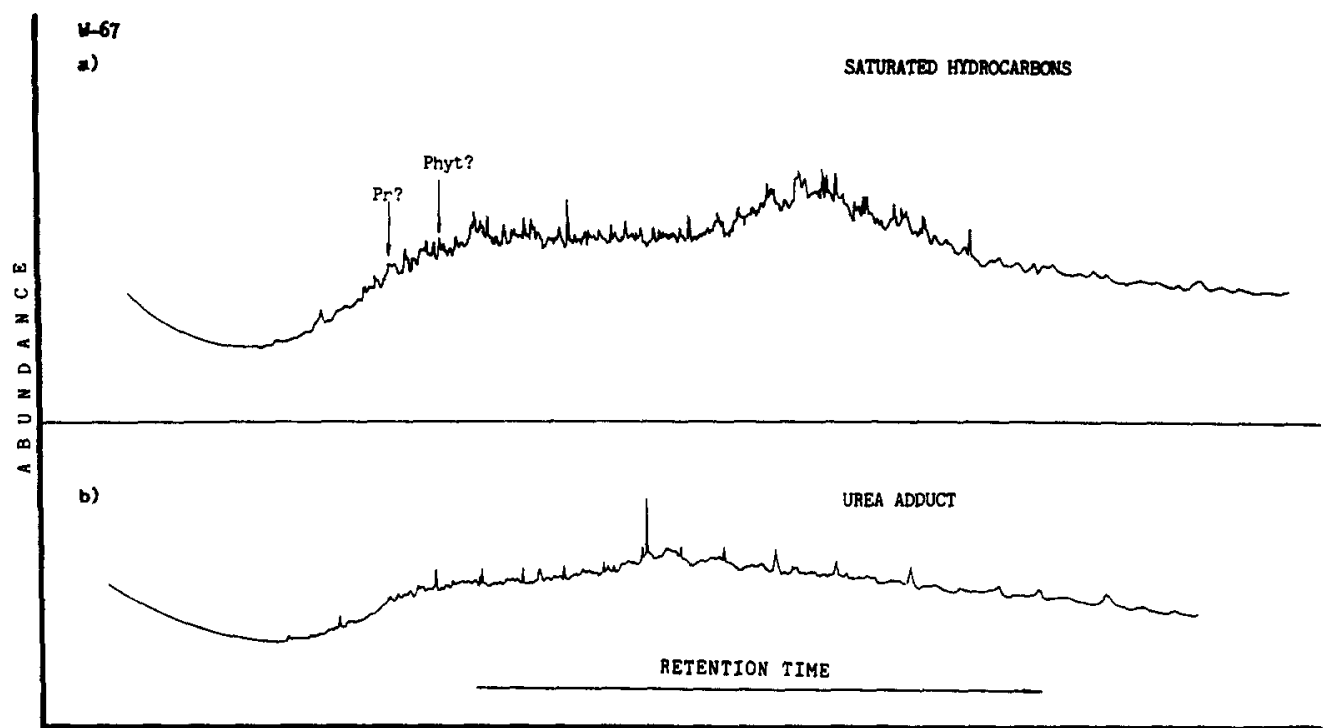

Fig. 5. Capillary gas chromatograms of the saturated hydrocarbons (a) and urea adduct (b) of the crude oil sample W-67, typical for moderate biodegradation.

The source parameters calculated from terpane biomarker distributions [Figs 6(a) and 6(b)] are presented in Table 3.

The ratio of $C_{23}$ tricyclic terpane and $C_{24}$ tetracyclic terpane (parameter 2, Table 3) is helpful in evaluating the contribution of marine $\left(\mathrm{C}_{23}\right.$-tricyclic) and terrestrial $\left(\mathrm{C}_{24}\right.$-tetracyclic) organic matters in oil generation (Philp, 1985). The values of this parameter for the analyzed oils show little variation (in the order of 1) and could indicate that the contributions of continental and marine organic matters in producing the oils sampled from 13 wells of field "W" were almost equal.

The oleanane $/ C_{30}$ hopane $\times 100$ parameter is about constant for the oil samples analyzed (12-14; par- ameter 3, Table 3). The presence of oleanane, an indicator of terrestrial inputs in predominantly Tertiary basins, mainly of deltaic nature (Ekweozer $e t$ al., 1979; Riva et al., 1986), as well as in Upper Cretaceous sediments (Riva et al., 1988), is more evidence of the participation of terrestrial organic matters in the genesis of the "W" oils.

The abundance of the pentacyclic triterpane gammacerane relative to $C_{30}$ hopane (parameter 4 , Table 3) is a useful parameter for evaluating the salinity of the environment of deposition of source rock, since high amounts of gammacerane are found in oils originated from marine evaporites and/or highly reducing saline environments. Only minor amounts of gammacerane were found in the oils

Table 3. Molecular source parameters of the analyzed oil samples

\begin{tabular}{|c|c|c|c|c|c|c|}
\hline & 1 & 2 & - 3 & 4 & 5 & 6 \\
\hline $\begin{array}{l}\text { Well } \\
\text { No }\end{array}$ & $\mathrm{Pr} / \mathrm{Py}$ & $C_{23} \underset{\text { Terpafes }}{\operatorname{tr} 1-/ C_{24}}$ tetra- & $\frac{\text { Oleanane }}{C_{30} \text { hop. }} \times 100$ & $\frac{\text { Gampacerane }}{C_{30} \text { hopane }} \times 100$ & ${ }_{\text {Hopanes }}$ & $\mathrm{Tm} / \mathrm{Ts}$ \\
\hline$w-120$ & 0.66 & 0.87 & 13 & 4.8 & 0.53 & 0.85 \\
\hline$W-126$ & 0.64 & 0.92 & 12 & 6.9 & 0.52 & 0.82 \\
\hline$W-98$ & 0.53 & 0.92 & 13 & 4.9 & 0.52 & 0.84 \\
\hline$w-88$ & 0.55 & ND & 15 & 9.2 & 0.45 & 0.96 \\
\hline$w-8$ & 0.52 & 1.05 & 13 & 7.6 & 0.51 & 0.74 \\
\hline$w_{i}-50$ & 0.52 & 0.96 & 13 & 6.8 & 0.54 & 0.85 \\
\hline$W-87$ & 0.46 & 0.94 & 14 & 9.0 & 0.48 & 1.07 \\
\hline$W-6$ & 0.40 & 1.04 & 14 & 6.8 & 0.51 & 0.88 \\
\hline$w-52$ & 0.45 & 1.01 & 13 & 6.6 & 0.52 & 0.90 \\
\hline$W-127$ & 0.33 & 1.18 & 13 & 4.9 & 0.54 & 0.87 \\
\hline$x-44$ & 0.40 & 0.97 & 13 & 6.9 & 0.48 & 0.63 \\
\hline$k-3$ & 0.40 & 1.02 & 12 & 6.6 & 0.48 & 0.78 \\
\hline h:-67 & 0.50 & 0.91 & 14 & 7.1 & 0.48 & 0.54 \\
\hline
\end{tabular}




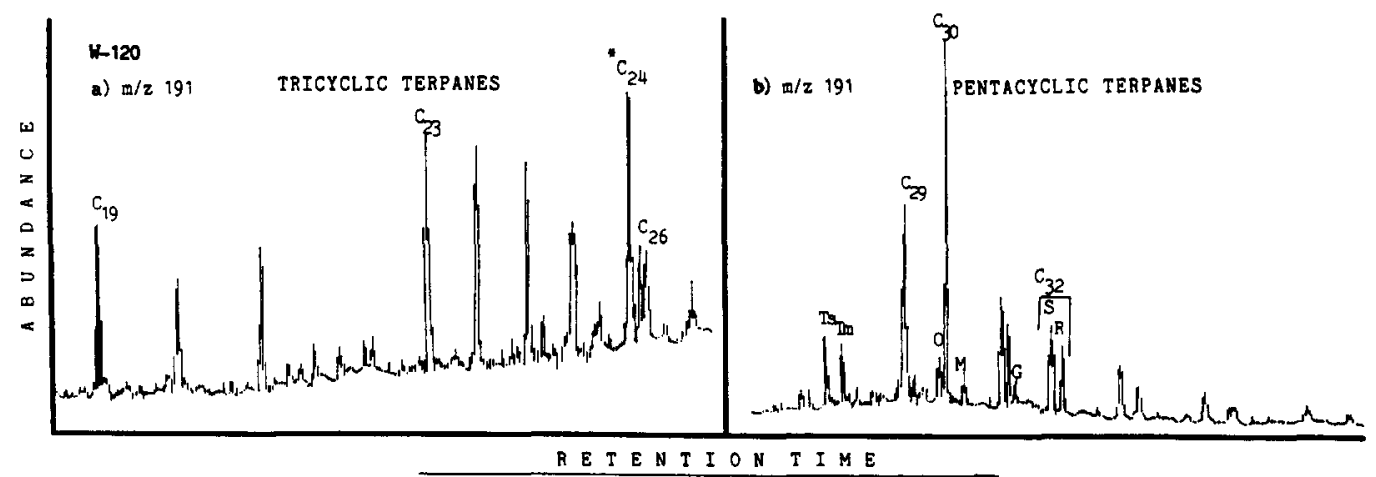

Fig. 6. Distributions of tri- and tetracyclic terpanes (a) and pentacyclic terpanes (b) of the crude oil sample W-120, typical for the crude oil samples studied. $C_{24}=$ tetracyclic terpane; Ts $=18 \alpha(\mathrm{H})-22,29,30$-trisnorhopane; $\mathrm{Tm}=17 \alpha(\mathrm{H})-22,29,30$-trisnorhopane; $\mathrm{O}=$ oleanane; $\mathrm{M}=$ moretane; and $\mathrm{G}=$ gammacerane.

derived from marine carbonates and lacustrine deposits (Mello et al., 1988). Gammacerane concentrations in the analyzed oil samples are low [Fig. 6(b) and Table 3], lower than the concentrations of oleanane. This may demonstrate that the " $W$ " oil is not derived from marine evaporites nor from a sediment deposited in highly reducing saline media.

The value of $\mathrm{C}_{29} / \mathrm{C}_{30}$ hopane for all the oil samples is $<1$ (parameter 5 , Table 3 ). This may be due to the Tertiary age of the oil (Pym et al., 1975). However, this parameter should help distinguish the mineral matrix of depositional environments. When the value of $\mathrm{C}_{29} / \mathrm{C}_{30}<1$, as for the analyzed oil samples, the marine carbonates may be eliminated in favor. of clays, shales and lacustrine carbonates as source rocks (Sofer, 1988).

The ratio of two isomers of $\mathrm{C}_{27}$ hopane, $17 \alpha(\mathrm{H})$ 22,29,30-trisnorhopane $(\mathrm{Tm})$ and $18 \alpha(\mathrm{H})-22,29,30$ trisnorhopane (Ts) (parameter 6, Table 3), is a maturity (Seifert and Moldowan, 1978) as well as source parameter since it enables mineralogic evaluation of the source rock (Seifert and Moldowan, 1981). Namely, Tm is converted to Ts during maturation provided the mineral matrix contains suitable catalysts such as clays and shales, but excluding carbonates.

Of the steranes biomarkers (Fig. 7), the distribution of regular (20R)- $\mathrm{C}_{27}-\mathrm{C}_{29}$ steranes can be used

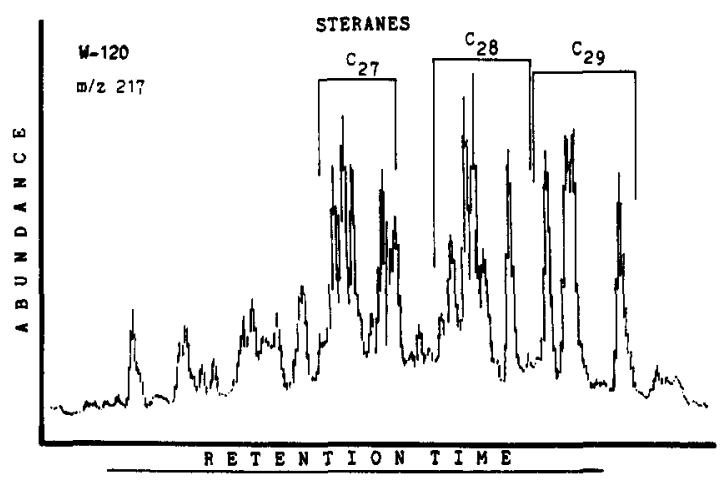

Fig. 7. Distribution of steranes of the crude oil sample W.120, typical for the crude oil samples studied. as a reliable parameter to evaluate the organic matter type of the depositional environment (Huang and Meinschein, 1978; Hoffman et al., 1984). The presence of $\mathrm{C}_{27}, \mathrm{C}_{28}$ and $\mathrm{C}_{29}$ regular steranes (data in the triangular plot, Fig. 8) leads to the conclusion that the analyzed oil was produced from residues of both continental and marine organisms deposited, probably, in deltas and/or brackish lakes.

The discussed molecular, source correlation parameters (Figs 6-8, Table 3) indicate that all the analyzed oil samples are of the same genetic type, that their origin can be traced to both terrestrial and marine organic input from a noncarbonate source rock.

The maturity of the " $W$ " oil can be evaluated using the maturation parameters in Table 4.

According to the $\mathrm{C}_{32}(22 S) /(22 S)+(22 R)$ hopanes and $\mathrm{C}_{29} \alpha \alpha(20 S) / \alpha \alpha(20 S)+(20 R)$ sterane maturation parameters, the maturity of the 13 analyzed oil samples is uniform and rather high as the epimerization reactions of hopane at C-22 and sterane at C-20 reach equilibrium according to the literature data (parameters 1 and 3, Table 4) (Mackenzie et al., 1982; Seifert and Moldowan, 1981).

The low ratio of the biolipid $\mathrm{C}_{30}$ moretane and geolipid $\mathrm{C}_{30}$ hopane (parameter 2, Table 4) indicates a low concentration of $17 \beta(\mathrm{H}), 21 \alpha(\mathrm{H})(22 R)$ epimer (moretane) in relation to the thermodynamically more stable geolipid isomer $17 \alpha(\mathrm{H}), 21 \beta(\mathrm{H})(22 R)$ hopane, and thereby a high maturity of all the tested oils.

The concentration of the thermodynamically more stable epimer Ts is higher in all samples than the concentration of the less stable Tm (parameter 6, Table 3). This again leads to the conclusion that the analyzed oil samples are highly mature. It was possible to use the $\mathrm{Tm} / \mathrm{Ts}$ ratio as a maturity correlation parameter after establishing that the analyzed samples originated from source rocks with the same or similar mineral matrix of noncarbonate type.

The epimers' $14 \alpha(\mathrm{H}), 17 \alpha(\mathrm{H})$ and $14 \beta(\mathrm{H}), 17 \beta(\mathrm{H})$ $\mathrm{C}_{29}(20 S+20 R)$ abundance ratio (parameter 4 , Table 4) is a maturity parameter, the value of which 


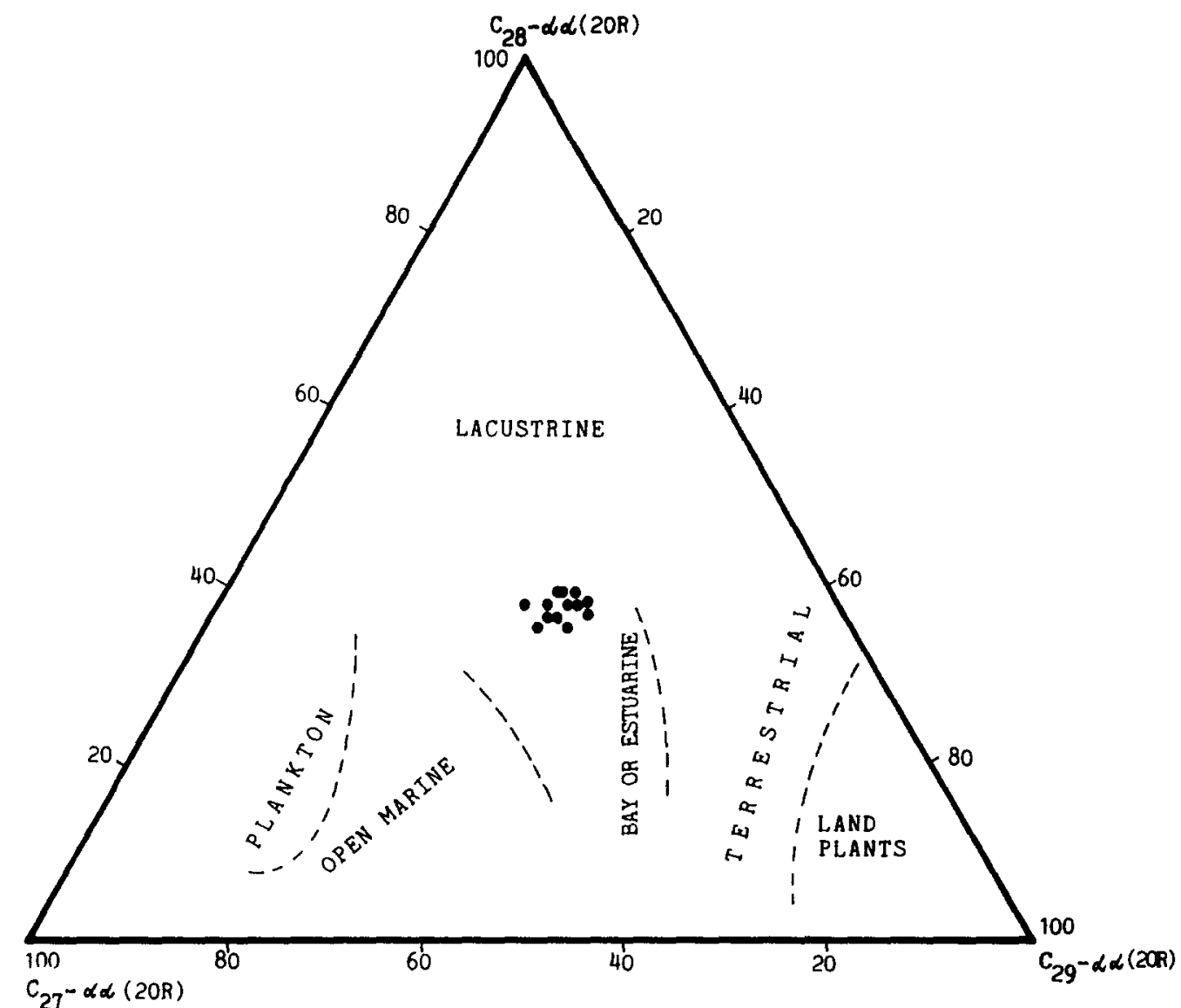

Fig. 8. Distribution of $\alpha \alpha \alpha(20 R) \mathrm{C}_{27}-\mathrm{C}_{29}$ steranes.

is some 0.7 when both epimerization reactions $(20 R=20 S$ and $\alpha \alpha=\beta \beta)$ reach equilibrium (Grantham, 1986). As indicated in Table 4, the values of this parameter are lower in all cases $(0.50-0.54)$. The incomplete isomerization of the normal steranes into isosteranes is probably due to the formation of isosteranes at a slower rate than the formation of $20 \mathrm{~S}$ regular steranes (Grantham, 1986).

The values of the discussed maturity parameters for the 13 tested oil samples fall within a narrow

Table 4. Molecular maturation parameters of the analyzed oil samples

\begin{tabular}{|c|c|c|c|c|c|c|}
\hline & 1 & 2 & 3 & 4 & 5 & 6 \\
\hline $\begin{array}{c}\text { Well } \\
\text { No }\end{array}$ & $c_{32} \frac{(22 S)}{\text { Hopanes }}$ & $\frac{c_{30} \text { moretane }}{c_{30} \text { hopane }}$ & 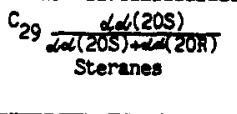 & 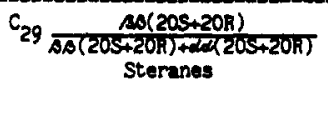 & $\frac{c_{20}}{C_{20}+C_{28}}$ & $\frac{c_{27}}{C_{28}}$ \\
\hline W- 120 & 0.58 & 0.098 & 0.51 & 0.52 & 0.54 & 1.13 \\
\hline W- 126 & 0.55 & 0.101 & 0.52 & 0.51 & 0.50 & 1.19 \\
\hline W-98 & 0.60 & 0.093 & 0.55 & 0.54 & 0.48 & 1.17 \\
\hline W-88 & 0.59 & 0.113 & 0.51 & 0.55 & ND & ND \\
\hline W-B & 0.57 & 0.093 & 0.53 & 0.50 & 0.55 & 1.14 \\
\hline W-50 & 0.58 & 0.093 & 0.54 & 0.52 & 0.53 & 1.20 \\
\hline$W-87$ & 0.54 & 0.118 & 0.52 & 0.52 & ND & ND \\
\hline$\dot{k}-6$ & 0.58 & 0.102 & 0.52 & 0.52 & 0.58 & 1.11 \\
\hline$W-52$ & 0.59 & 0.091 & 0.53 & 0.54 & 0.54 & 1.26 \\
\hline$W-127$ & 0.58 & 0.092 & 0.55 & 0.53 & 0.48 & 1.12 \\
\hline$w-44$ & 0.58 & 0.085 & 0.52 & 0.53 & 0.52 & 1.19 \\
\hline$k-3$ & 0.60 & 0.082 & 0.53 & 0.52 & 0.52 & 1.04 \\
\hline$n-67$ & 0.57 & 0.085 & 0.53 & 0.52 & 0.62 & 1.25 \\
\hline
\end{tabular}




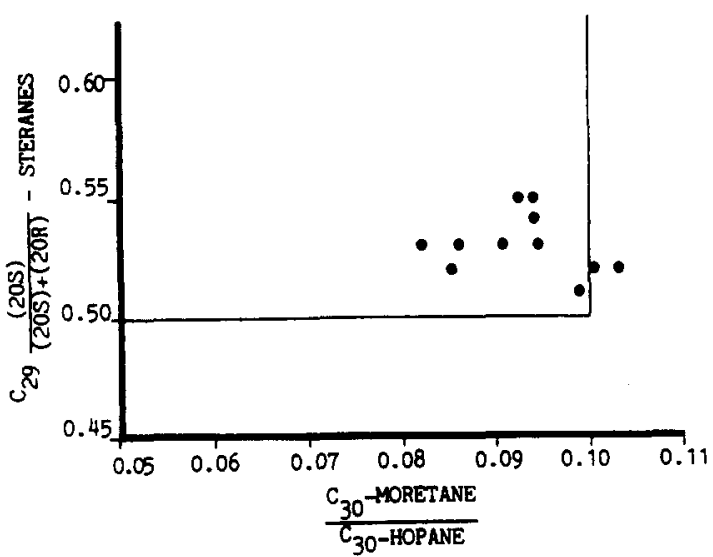

Fig. 9. Cross plot of the $\mathrm{C}_{29}$ sterane isomerization parameter $20 S /(20 S+20 R)$ against $C_{30}$ moretane $/ 17 \alpha(\mathrm{H})$ hopane ratios in crude oils, "W" field.

range (Table 4) and probably demonstrate the unique origin of the "W" oil.

Figure 9 shows a plot of two maturity parameters: $\mathrm{C}_{29}$ steranes $\alpha \alpha(20 S) /(20 S+20 R)$ and $\mathrm{C}_{30}$ moretane/hopane. Both parameters exhibit low rates of the isomerizations $(20 R) \rightarrow(20 S)$ and $\mathrm{C}_{30}$ moretane $\rightarrow \mathrm{C}_{30}$ hopane so that the $70 \mathrm{Myr}$ of Tertiary do not seem sufficient for reaching equilibrium, even if the source rocks were in a high temperature gradient (Grantham, 1986). After Grantham (1986) the $C_{30}$ moretane/hopane and $\mathrm{C}_{29}(20 S) /(20 S)+(20 R)$ ratios of the Tertiary oils are $0.1-0.3$ (usually $0.15-0.20$ ) and $0.18-0.50$ (usually $0.35-0.48$ ), respectively. In view of the above data and of the values resulting from " $W$ " oil (Table 4, Fig. 9), it could be stated with a high degree of reliability that the analyzed "W" oils originate from Pre-Tertiary source rocks.

The absence of monoaromatic steranes and the distribution of triaromatic steranes seems to support the high and uniform maturity of the tested oils (Shi et al., 1982). As an example, Fig. 10 contains $m / z 231$ and $m / z 253$ fragmentograms for W-120.

The absence of monoaromatic steranes and the relatively high concentration of triaromatic steranes, $\mathrm{C}_{20}$ and $\mathrm{C}_{21}$, in all cases confirm once again the uniform and high maturity of the tested crudes from the "W" field.
Besides geologic time, temperature is another very important factor for epimerization of $\mathrm{C}_{30}$ moretane to $\mathrm{C}_{30}$ hopane and aromatization of sterane (Mackenzie et al., 1983; Grantham, 1986). The conclusion that can be drawn from the data contained in Table 4 (parameters 2-6) and Figs 9 and 10 is that the source rocks of the tested oil samples were subject to high temperatures.

\section{CONCLUSIONS}

The study of the composition of hydrocarbon fractions proved that the " $W$ " crude oil was biodegraded with a loss of $n$-alkanes. The intensity of biodegradation varied within the oil field. It was most intense in the northeast part (W-3, W-44, W-67) where the isoprenoid alkanes pristane and phytane were found only in trace amounts; biodegradation seems to be associated in this part of the field with the inclined oil-water contact. The lowest temperature and the highest pressure gradients were recorded for this same part of the reservoir also. Somewhat lower biodegradation was observed for the small Miocene hydrocarbon accumulation (W-120 and W-126), indicating its bad, if any communication with the aquifer associated with the main pool. The observed biodegradation in the "W" crude oil seems to be the main cause for the different nature of this oil compared with most other oils discovered to date in the southeast part of the Pannonian basin.

On the basis of bulk and biomarker parameters it can be concluded that all the crude oil samples studied have mainly uniform composition. The crude oil probably has a mixed terrestrial-marine origin, and derives from argillaceous source rocks sedimented in marine delta or brackish lakes. It could be proposed that the "W" oil migrated to the reservoir rocks through the Post-Triassic fault.

Specific maturation parameters confirmed that the "W" crude oil has reached a quite uniform and significant thermal maturation. Considering maturation parameters such as the ratios $\mathrm{C}_{30}$ moretane/ hopane and $\mathrm{C}_{29} \alpha \alpha(20 S) / \alpha \alpha(20 S)+(20 R)$ steranes, as well as the presence of oleanane, it could be proposed that the " $W$ " oil originates from a Pre-
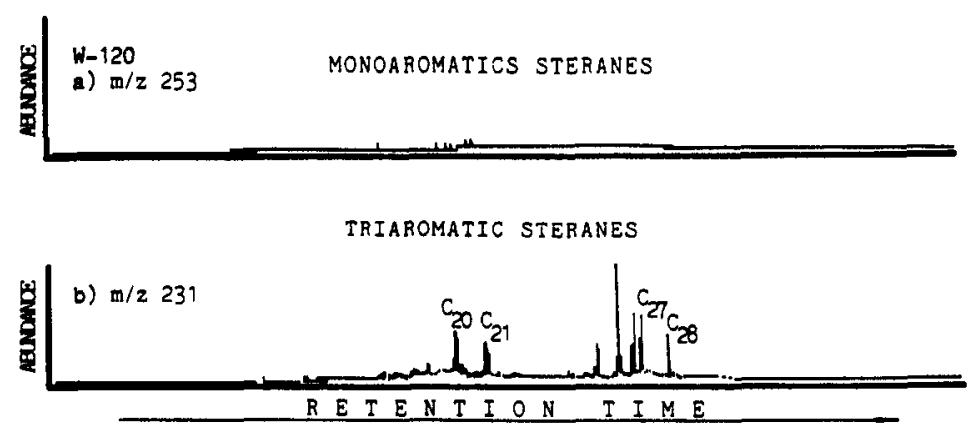

Fig. 10. Distributions of monoaromatic (a) and triaromatic steranes (b) of the crude oil sample W-120, typical for the crude oil samples studied. 
Tertiary source rock, at least an Upper Cretaceous one, unlike most Pannonian basin oils which are Tertiary in age.

Acknowledgements - The authors would like to thank to Dr A. Hollerbach for the use of GC-MS at the Institute for Petroleum Research (Clausthal-Zellerfeld) and to Nafta-gas (Novi Sad) for the oil samples and permission to publish the results. This work was supported in part by the Research Fund of the S. R. Serbia (Yugoslavia).

\section{REFERENCES}

Aksin B. (1967) Theoretical problems concerning the classification of oil gas deposits. The significance of the classification for exploration with a special consideration of the deposits in Banat (in Serbo-Croatian). Institute for Geological and Geophysical Investigations, Belgrade.

Alexander R., Kagi R. I., Woodhouse G. W and Volkman J. (1983) The geochemistry of some biodegraded Australian oils. APEA 23, 53-62.

Ekweozor C. M., Okogun J. I., Ekong D. E. U. and Maxwell J. R. (1979) Preliminary organic geochemical studies of samples from the Niger Delta (Nigeria). I. Analysis of crude oils for triterpanes. Chem. Geol. 27, 11-28.

Gajin S. (1989) Personal communication.

Grantham P. J. (1986) Sterane isomerisation and moretane/hopane ratios in crude oils derived from Tertiary source rocks. Org. Geochem. 9, 293-304.

Haven H. L. ten, Leeuw J. W. de and Schenck P. A. (1985) Organic geochemical studies of a Messinian evaporitic basin, northern Appenines (Italy): hydrocarbon biological markers for a hypersaline environment. Geochim. Cosmochim. Acta 49, 2181-2191.

Haven H. L. ten, Leeuw J. W. de, Rullkötter J. and Sinninghe Damsté (1987) Can the pristane/phytane ratio be used as a paleoenvironmental indicator? Nature (London) 330, 641-643.

Hoffmann C. F., Mackenzie A. S., Lewis C. A., Maxwell J. R., Oudin I. L., Durand B. and Vandenbroucke M. A. (1984) A biological marker study of coals, shales and oils from Mahakam delta, Kalimantan, Indonesia. Chem. Geol. 42, 1-23.

Huang W. Y. and Meinschein W. G. (1978) Sterols in sediments from Baffin Bay, Texas. Geochim. Cosmochim. Acta 42, 1391-1396.

Karović G., Jovanović M. and Zečević V. (1969) The Velebit oil Reservoir (Bačka). Nafta 5, 217-221.

Mackenzie A. S., Lamb N. A. and Maxwell J. R. (1982) Steroid hydrocarbons and the thermal history of sediments. Nature (London) 295, 223-226.

Mackenzie A. S., Li R.-W., Maxwell J. R., Moldowan J. M. and Seifert W. K. (1983) Molecular measurements of thermal maturation of Cretaceous Shales from the Overthrust Belt, Wyoming, U.S.A. In Advances in Organic Geochemistry 1981 (Edited by Bjorøy M. et al.), pp. 496-503. Wiley, Chichester.

Mello M. R., Gaglianone P. C., Brassel S. C. and Maxwell J. R. (1988) Geochemical and biological marker assessment of depositional environments using Brazilian offshore oils. Mar. Pet. Geol. 3, 205-223.
Palacas I. G., Monopolis D., Nicolaon C. A. and Anders D. E. (1986) Geochemical correlation of surface and subsurface. oils, Western Greece. In Advances in Organic Geochemistry 1985 (Edited by Leythaeuser D. and RulIkötter J.). Org. Geochem. 10, 417-423. Pergamon Press, Oxford.

Philippi G. T. (1977) On the depth, time and mechanism of origin of the heavy to medium-gravity naphthenic crude oils. Geochim. Cosmochim. Acta 41, 33-52.

Philp R. P. (1985) In Fossil Fuel Biomarkers. Elsevier, Amsterdam.

Powell T. G. and McKirdy D. M. (1973) Relationship between ratio of pristane to phytane, crude oil composition and geological environment in Australia. Nature (London) Phys. Sci. 243, 37-57.

Price L. C. (1980) Crude oil degradation as an explanation of the depth rule. Chem. Geol. 28, 1-30.

Pym J. G., Ray J. E., Smith G. W. and Whitehead E. V. (1975) Petroleum triterpane fingerprinting of crude oils. Anal. Chem. 47, 1617-1622.

Riva A., Salvatori T., Cavaliere R., Ricchiuto T. and Novelli L. (1986) Origin of oils in Po Basin, Northern Italy. In Advances in Organic Geochemistry 1985 (Edited by Leythaeuser D. and Rullkötter J.). Org. Geochem. 10, 391-400. Pergamon Press, Oxford.

Riva A., Caccialanza P. G. and Quagliaroli F. (1988) Recognition of $18 \beta(\mathrm{H})$ oleanane in several crudes and Tertiary-Upper Cretaneous sediments. Definition of a new maturity parameter. In Advances in Organic Geochemistry 1987 (Edited by Mattavelli L. and Novelli L.). Org. Geochem. 13, 671-675. Pergamon Press, Oxford.

Šaban M., Jovančićević B. S., Saračević S., Hollerbach A. and Vitorovic D. (1988) Correlative geochemical study of crude oils from southeastern and southern parts of the Pannonian Basin. In Advances in Organic Geochemistry 1987 (Edited by Mattavelli L. and Novelli L.). Org. Geochem. 13, 325-333. Pergamon Press, Oxford.

Sarković M. (1972) Ph.D. thesis, University of Belgrade.

Seifert W. K. and Moldowan J. M. (1978) Applications of steranes, terpanes and monoaromatics to the maturation, migration and source of crude oils. Geochim. Cosmochim. Acta 42, 77-95.

Seifert W. K. and Moldowan J. M. (1981) Paleoreconstruction by biological markers. Geochim. Cosmochim. Acta 45, 783-794.

Shi J.-Y., Mackenzie A. S., Alexander R., Eglinton G., Gowar A. P., Wolff G. A. and Maxwell J. R. (1982) A biological marker investigation of petroleums and shales from the Shangli oil field, Peoples Republic of China. Chem. Geol. 35, 1-31.

Sofer Z. (1988) Hydrous pyrolysis of Monterey asphaltenes. In Advances in Organic Geochemistry 1987 (Edited by Mattavelli $L$ and Novelli L.). Org. Geochem. 13, 939-945. Pergamon Press, Oxford.

Volkman J. K., Alexander R., Kagi R. I. and Woodhouse G. W. (1983) Demethylated hopanes in crude oils and their applications in petroleum geochemistry. Geochim. Cosmochim. Acta 47, 785-794.

Waples D. W. (1985) Geochemistry in Petroleum Exploration. Inter. Human Resources Development Corp., Boston, MA.

Welte D. H. and Waples D. W. (1973) Über die Bevorzugung geradzahliger $n$-Alkane in Sedimentgesteinen. Naturwissenschaften 60, 516-517. 